1 Title:

2 Cohorting KPC+Klebsiella pneumoniae (KPC-Kp) positive patients - a genomic exposé of cross-

3 colonization hazards in a long-term acute care hospital (LTACH)

\title{
4 Authors:
}

5 Shawn E. Hawken, MPH ${ }^{1}$

$6 \quad$ Mary K. Hayden, $\mathrm{MD}^{3}$

$7 \quad$ Karen Lolans, $\mathrm{BS}^{3}$

8 Rachel D. Yelin, $\mathrm{MPH}^{3}$

$9 \quad$ Robert A. Weinstein, $\mathrm{MD}^{3}$

10 Michael Y. Lin, $\mathrm{MD}^{3}$

11 Evan S. Snitkin, $\mathrm{PhD}^{1,2}$

\section{Affiliations:}

13 Departments of Microbiology \& Immunology ${ }^{1}$ and Internal Medicine division of infectious diseases ${ }^{2}$

14 University of Michigan Medical School, Ann Arbor, MI, USA. Division of Infectious diseases, Rush

15 University Medical Center, Chicago, IL, USA ${ }^{3}$

\section{Corresponding author:}

17 Evan Snitkin,

18 1520D MSRB I

191150 W. Medical Center Dr.

20 Ann Arbor, MI, 48109-5680

21 Tel- (734) 647-6472

22 Fax- 734-615-5534

23 Email- esnitkin@umich.edu 
medRxiv preprint doi: https://doi.org/10.1101/2020.02.07.20020669; this version posted February 7, 2020. The copyright holder for this preprint (which was not certified by peer review) is the author/funder, who has granted medRxiv a license to display the preprint in perpetuity.

It is made available under a CC-BY-NC-ND 4.0 International license.

\section{Abbreviated title:}

25 Cohorting and KPC-Kp Cross-Colonization

26 Word count: 2,626

27 
medRxiv preprint doi: https://doi.org/10.1101/2020.02.07.20020669; this version posted February 7, 2020. The copyright holder for this preprint (which was not certified by peer review) is the author/funder, who has granted medRxiv a license to display the preprint in perpetuity.

It is made available under a CC-BY-NC-ND 4.0 International license.

\section{Abstract}

Objective: Cohorting patients who are colonized or infected with multidrug-resistant organisms (MDROs) has been demonstrated to protect uncolonized patients from acquiring MDROs in healthcare settings. A neglected aspect of cohorting is the potential for cross-transmission within the cohort and the possibility of colonized patients acquiring secondary isolates with additional antibiotic resistance traits. We searched for evidence of cross-transmission of KPC+Klebsiella pneumoniae (KPC-Kp) colonization among cohorted patients in a long-term acute care hospital (LTACH), and evaluated the impact of secondary acquisitions on resistance potential.

Design: Genomic epidemiological investigation

Setting: A high-prevalence LTACH during a bundled intervention that included cohorting KPC-Kppositive patients.

Methods: Whole-genome sequencing (WGS) and location data were analyzed to identify potential cases of cross-transmission between cohorted patients.

Results: Secondary KPC-Kp isolates from 19 of 28 admission-positive patients were more closely related to another patient's isolate than to their own admission isolate. In 14 of these 19 cases there was strong genomic evidence for cross-transmission $(<10$ SNVs) and the majority of these patients occupied shared cohort floors (12 cases) or rooms ( 5 cases) at the same time. Of the 14 patients with strong genomic evidence of acquisition, 12 acquired antibiotic resistance genes not found in their primary isolates.

Conclusions: Acquisition of secondary KPC-Kp isolates carrying distinct antibiotic resistance genes was detected in nearly half of cohorted patients. These results highlight the importance of healthcare provider adherence to infection prevention protocols within cohort locations, and motivate future studies to assess whether multiple-strain acquisition increases risk of adverse patient outcomes. 
medRxiv preprint doi: https://doi.org/10.1101/2020.02.07.20020669; this version posted February 7, 2020. The copyright holder for this preprint (which was not certified by peer review) is the author/funder, who has granted medRxiv a license to display the preprint in perpetuity.

It is made available under a CC-BY-NC-ND 4.0 International license .

\section{Introduction}

Cohorting of patients who are colonized or infected with high-priority healthcare pathogens has been demonstrated to prevent the spread of healthcare associated infections (HAIs). ${ }^{1}$ Cohorting works by physically separating colonized or infected patients together in one area for care, thereby preventing contact with other patients. ${ }^{1}$ In addition to being effective in outbreak settings, ${ }^{2-5}$ cohorting has been demonstrated to reduce cross-transmission in endemic healthcare settings with high colonization pressure, such as long-term acute care hospitals (LTACHs). ${ }^{6,7}$

Carbapenem resistant enterobacteriaceae (CRE) are multi-drug resistant organisms (MDROs) that are resistant to nearly all antibiotics and that are estimated to be responsible for 8,500 infections and 1,100 deaths in the U.S. annually. ${ }^{8} \mathrm{CRE}$ have been labeled an urgent public health threat for nearly a decade, but despite wide-spread attention, infections with CRE have not decreased. ${ }^{8}$ Previous work has shown that LTACHs have a disproportionately high prevalence of CRE and that they likely contribute to transmission across regions. ${ }^{9,10}$ Encouragingly, a recent study demonstrated the effectiveness of a bundled intervention that included cohorting CRE-positive patients to reduce a particular type of CRE-Klebsiella pneumoniae that carry the KPC-type of carbapenemase (KPC-Kp )-- in a LTACH with high KPC-Kp prevalence. ${ }^{11}$ This study highlights the potential for infection prevention interventions to reduce transmission in these complex and healthcare settings with a heavy burden of MDROs. ${ }^{11}$ Guidelines for preventing transmission in healthcare settings recommend placing "together in the same room (cohort) patients who are infected or colonized with the same pathogen" when single-patient rooms are unavailable. ${ }^{1}$ Yet molecular and phenotypic analyses of prominent healthcare pathogens like CRE indicate that strains of a given antibiotic resistance type are not necessarily equivalent in terms of resistance mechanisms and virulence genes. ${ }^{12,13}$ Cross-transmission of genetically diverse strains among cohorted patients could have clinically important consequences. First, patients are often treated 
medRxiv preprint doi: https://doi.org/10.1101/2020.02.07.20020669; this version posted February 7, 2020. The copyright holder for this preprint (which was not certified by peer review) is the author/funder, who has granted medRxiv a license to display the preprint in perpetuity.

It is made available under a CC-BY-NC-ND 4.0 International license .

75 empirically based on susceptibility results from prior cultures. ${ }^{14-16}$ However, if a patient acquires new strains, this empiric antibiotic treatment strategy may fail because the secondary organism could carry different antibiotic resistance genes and therefore have a different susceptibility profile. ${ }^{13,17,18}$

Additionally, recent reports provide evidence in support of horizontal transfer of antibiotic resistance genes within patients, ${ }^{19,20}$ indicating that co-colonization with multiple strains can lead to entry of resistance genes into new genetic backgrounds. sample of patients from a comprehensive surveillance study of KPC-Kp colonization in a Chicago

LTACH. ${ }^{11}$ We hypothesized that by integrating whole-genome sequencing (WGS) and patient location

84 data we would identify KPC-Kp colonized patients with evidence of acquisition of distinct secondary

85 KPC-Kp strains through cross-transmission from other patients co-housed in cohort locations.

86 Moreover, we predicted that secondary acquired strains would harbor antibiotic resistance genes that 87 were not found in the patient's admission isolate.

Methods

\section{LTACH setting, study design and sample collection}

91 Detailed information regarding the study design, intervention bundle and data collection are available in

92 Hayden et. al 2015. ${ }^{11}$ Briefly and of relevance to the current manuscript, the study took place between

93 2011-2013 during a quality improvement project to prevent KPC-Kp colonization and infection in a

94 Chicago LTACH where the average prevalence of KPC-Kp colonization was $30 \%$. All location data and

95 isolates presented here were collected from one LTACH during the intervention period,which included

96 surveillance swab culture-based screening of all LTACH patients for KPC-Kp rectal colonization at

97 LTACH admission and every two weeks (94\% adherence), as well as efforts to separate KPC-Kp- 
medRxiv preprint doi: https://doi.org/10.1101/2020.02.07.20020669; this version posted February 7, 2020. The copyright holder for this preprint (which was not certified by peer review) is the author/funder, who has granted medRxiv a license to display the preprint in perpetuity.

It is made available under a CC-BY-NC-ND 4.0 International license .

98 positive and KPC-Kp-negative patients by placing KPC-Kp-positive patients in ward cohorts $(91 \%$

99 adherence). ${ }^{7}$ Participating LTACHs deemed the study to be a quality improvement project and not

100 research. The project was reviewed and determined to be a minimal-risk study by the institutional

101 review board at Rush University Medical Center, which granted approval of the study along with a

102 waiver of consent and Health Insurance Portability and Accountability Act waiver. ${ }^{11}$

103

104 Longitudinal convenience sample of KPC-Kp isolates from previously colonized patients

105 During the course of the original study, the first KPC-Kp surveillance isolate was collected from each

106 colonized patient. ${ }^{11}$ Once a patient was found to be colonized with KPC-Kp, the patient was presumed to

107 remain colonized indefinitely. Colonized patients were not rescreened systematically; however,

108 additional 'secondary' KPC-Kp isolates were collected from a subset of patients whose prior

109 colonization status was unclear to study staff at the time of screening.

The current analyses are restricted to this longitudinal, convenience sample of patients who were

111 KPC-Kp positive at the study start or upon LTACH admission (within 3 days) and who also had one or

112 more additional KPC-Kp surveillance isolates collected later. These 'index' patients were selected for

113 study because they were housed in cohort locations during their entire LTACH stay, providing long

114 periods of exposure to other KPC-Kp positive patients and potential opportunities for cross-

115 transmission.

116 Among the index patients who had secondary isolates available, $100 \%$ were cohorted per-

117 protocol: 21 patients with 46 secondary isolates shared a room with at least 1 patient who was KPC-Kp-

118 positive before their secondary isolate being collected, and 8 patients with 15 secondary isolates did not

119 have overlap with a positive patient before their secondary isolate was collected, but were instead

120 housed in single patient rooms during the acquisition time frame for these isolates. Isolates from the 21 
medRxiv preprint doi: https://doi.org/10.1101/2020.02.07.20020669; this version posted February 7, 2020. The copyright holder for this preprint (which was not certified by peer review) is the author/funder, who has granted medRxiv a license to display the preprint in perpetuity.

It is made available under a CC-BY-NC-ND 4.0 International license .

121 patients who shared a room with a putative KPC-Kp-positive donor prior to secondary acquisition were 122 collected after patients shared a room with positive patients for a median of 51 days (range 1-132 days) 123 prior to detection of a secondary isolate.

$125 \quad$ Whole-genome sequencing

126 DNA was extracted with the MoBio PowerMag Microbial DNA kit and prepared for sequencing on an 127 Illumina MiSeq instrument using the NEBNext Ultra kit and sample-specific barcoding. Library 128 preparation and sequencing were performed at the Center for Microbial Systems at the University of 129 Michigan or the University of Michigan Sequencing Core. Quality of reads was assessed with FastQC, ${ }^{21}$ 130 and Trimmomatic ${ }^{22}$ was used for trimming adapter sequences and low-quality bases. Assemblies were 131 performed using the A5 pipeline with default parameters. ${ }^{23}$ Sequence data are available under BioProject 132 PRJNA603790.

134 Identification of single nucleotide variants

135 SNV calling was performed as in Han et al. ${ }^{24}$ The variant calling pipeline can be found at 136 https://github.com/Snitkin-Lab-Umich/variant_calling_pipeline. To summarize, variant calling was 137 performed with samtools ${ }^{25}$ using the reference genomes listed in Supplementary table 1.

141 Epidemiologically plausible donor patient isolates were defined as isolates collected before the recipient 142 patient's secondary isolate collection date. To account for acquisition potentially occurring between 
medRxiv preprint doi: https://doi.org/10.1101/2020.02.07.20020669; this version posted February 7, 2020. The copyright holder for this preprint (which was not certified by peer review) is the author/funder, who has granted medRxiv a license to display the preprint in perpetuity.

It is made available under a CC-BY-NC-ND 4.0 International license .

143 surveillance sampling dates, the positive donor time-frame for all analyses was defined starting on the

144 date of the donor's last negative swab before the collection date of the putative donor isolate.

was assessed to identify spatiotemporal exposures in shared patient rooms that plausibly facilitated

147 secondary acquisition between roommates. Plausible secondary acquisitions linked to roommate

148 exposures were defined as acquisitions between a donor and recipient patient who occupied the same

149 room when the donor was considered positive for the putative donor isolate and prior to the collection

150 date of the recipient's secondary isolate.

151

Genetic relationships between KPC-Kp isolates based on SNV distance

153 Pairwise distances were calculated from core and accessory genome single-nucleotide variants (SNVs)

154 in whole-genome sequence alignments for each MLST represented by study isolates (Supplementary

155 table 1). SNV distances were compared (1) between the first (primary) and later collected (secondary)

156 isolates from the same index patient and (2) between secondary isolates from index patients and isolates

157 from other plausible donor patients in the LTACH.

158

Detection of resistance genes in whole genome sequences

160 Kleborate (https://github.com/katholt/Kleborate) was used to screen whole-genome sequence assemblies

161 for presence of genes and mutations known to confer antibiotic resistance in K pneumoniae. We used a

162 custom R script to expand antibiotic resistance gene alleles reported from Kleborate into gene presence

163 absence profiles (Supplementary table 1), counting only the Kleborate-reported precise matching gene

164 hits as being present or absent. 
medRxiv preprint doi: https://doi.org/10.1101/2020.02.07.20020669; this version posted February 7, 2020. The copyright holder for this preprint (which was not certified by peer review) is the author/funder, who has granted medRxiv a license to display the preprint in perpetuity.

It is made available under a CC-BY-NC-ND 4.0 International license .

\section{Results}

Almost half of cohorted patients acquired secondary isolates of a new sequence type

We considered 127 'index' patients, who were either positive at the start of the study or on first admission to the LTACH, for potential acquisition of secondary KPC-Kp strains during their stay. Although the original sampling strategy was not designed to track longitudinal colonization of KPC$\mathrm{Kp},{ }^{11}$ there were 28 index patients who in addition to their 38 'primary' isolates (earliest isolate) collected on admission or study start, also had 63 'secondary' isolates collected later during their LTACH stays (Figure 1). Of the 101 isolates available from these index patients, we extracted quality WGS data from 99 isolates including 38 primary and 61 secondary isolates. While the majority of primary and secondary isolates were from the epidemic ST258 strain (55\% of primary isolates, $57 \%$ of secondary isolates), a diversity of other multi-locus sequence types (MLSTs) was observed among both primary and secondary isolates (Supplemental Table 1). Secondary isolates were collected from patients a median of 89 days (range 1-310 days) after primary isolates. Evaluation of MLSTs of the primary and secondary KPC-Kp isolates provided support for secondary acquisition among cohorted patients, with $13(46 \%)$ patients having a distinct secondary MLST that was not detected at admission.

\section{Genomic evidence of potential secondary acquisitions from other LTACH patients among admission-}

\section{positive index patients}

To assess genomic evidence of cross-transmission in the cohort we evaluated the fraction of patients whose secondary isolates were more closely related to another patient's isolate than to their own primary isolate (Figure 2). Of the 28 index patients with one or more secondary isolates, 19 had a secondary isolate that was more closely related to another patient's isolate than to their own primary isolate. Of those 19 patients, 17 had secondary isolates that were more closely related to an isolate from 
medRxiv preprint doi: https://doi.org/10.1101/2020.02.07.20020669; this version posted February 7, 2020. The copyright holder for this preprint (which was not certified by peer review) is the author/funder, who has granted medRxiv a license to display the preprint in perpetuity.

It is made available under a CC-BY-NC-ND 4.0 International license .

189 a patient with whom they overlapped on the cohort floor and 8 had secondary isolates that were more

190 closely related to an isolate from a roommate. Plausible transmission in the cohort was further supported

191 by extremely small SNV distances in most of these cases, with 12 patients' isolates being within 10

192 SNVs of another patient's isolate on the cohort floor and 4 patients' isolates being within 10 SNVs of an

193 isolate from a roommate (Table 1).

194

195 Patients accumulate diverse antibiotic resistance genes in association with acquisition of a secondary

$196 \quad$ KPC-Kp isolate

197

There is an abundance of molecular and genomic evidence that members of the same bacterial

species, including KPC-Kp, can vary extensively in the arsenal of antibiotic resistance genes encoded in

199 their chromosomes and plasmids. ${ }^{12,26,27}$ To determine whether secondary acquisitions resulted in

200 increased antibiotic resistance potential we examined whether patients with high-confidence putative

201 transmission links ( $<10$ SNVs to another patient's isolate and $>10$ SNVs from their own primary isolate)

202 acquired additional unique resistance genes in their secondary isolate. As compared to a patient's

203 primary isolate, secondary isolates contributed a median of 2.5 additional antibiotic resistance genes

204 beyond the primary isolate (minimum 0, maximum 10 additional resistance genes) (Table 2). In total,

205 additional resistance genes were gained in 12 of the 14 patients whose secondary isolates had strong

206 genomic links to isolates from other patients, including 3 patients whose secondary isolates were linked

207 to patients with whom they had shared a cohort room prior to secondary isolate acquisition (Figure 3,

208 supplementary table 1, Patients with unlinked secondary isolates accumulated fewer additional

209 resistance genes (median 0, minimum 0, maximum 2 additional resistance genes) (supplementary figure

210 1). ). This finding supports the hypothesis that these closely related isolates ( $<10$ SNVs $)$ represented 
medRxiv preprint doi: https://doi.org/10.1101/2020.02.07.20020669; this version posted February 7, 2020. The copyright holder for this preprint (which was not certified by peer review) is the author/funder, who has granted medRxiv a license to display the preprint in perpetuity.

It is made available under a CC-BY-NC-ND 4.0 International license .

211 primary isolates that accrued mutations over the course of prolonged colonization rather than that

212 patients acquired a secondary KPC-Kp strain via transmission from another patient.

\section{Discussion}

Cohorting patients who are colonized or infected with MDROs is an effective strategy to reduce the risk of MDRO transmission to uncolonized patients. However, little attention has been paid to the

217 potential for cohorted patients themselves to acquire secondary resistant strains through exposure to the

218 high colonization pressure of MDROs within cohorts. Secondary strain acquisition may be particularly 219 important in endemic settings where the MDRO for which patients are cohorted, e.g. CRE, may comprise a heterogeneous group of bacteria with varying genetic potential. In order to investigate this risk, we performed a genomic epidemiologic investigation of a longitudinal, convenience sample of

222 KPC-Kp isolates from patients on cohort floors in a LTACH. We found strong evidence of cross223 transmission within cohorts, with secondary acquired isolates often harboring antibiotic resistance genes 224 not found within a patient's primary isolate.

Our finding that secondary isolates carry antibiotic resistance potential that is distinct from that

227 found in patients' primary isolates is noteworthy because it suggests that multiple strain acquisition 228 could increase risk of treatment failure. Acquisition of a secondary strain that is resistant to antibiotics to 229 which the primary strain was susceptible could be particularly problematic for highly resistant 230 organisms like KPC-Kp, which already have limited treatment options. For example, 231 colistin/polymyxin $\mathrm{E}$ is a last-resort drug that is used to treat severe multidrug-resistant gram negative 232 infections, such as those due to KPC-Kp. ${ }^{28-31}$ In our study, one patient plausibly acquired a secondary 233 isolate with predicted colistin resistance that was linked within 25 SNVs of another LTACH patient's 
medRxiv preprint doi: https://doi.org/10.1101/2020.02.07.20020669; this version posted February 7, 2020. The copyright holder for this preprint (which was not certified by peer review) is the author/funder, who has granted medRxiv a license to display the preprint in perpetuity.

It is made available under a CC-BY-NC-ND 4.0 International license .

234 isolate (supplementary table 1). As colonization is a major risk factor for KPC-Kp infection, ${ }^{32-34}$ and 235 infections are thought to arise primarily from the patient's colonizing strain, ${ }^{35}$ the acquisition of a 236 colistin resistant isolate could limit efficacious treatment options and in turn increase mortality risk. ${ }^{31,36}$ 237 In addition to the potential risks to multiply colonized patients, the acquisition of strains with different 238 resistance arsenals provides an opportunity for horizontal gene exchange and the accumulation of 239 resistance within a single transmissible strain. ${ }^{19,20,37}$ Moreover, harboring genetically diverse strains 240 creates an opportunity for resistance alleles to find their way to strains with other clinically relevant 241 characteristics, such as hyper-virulence ${ }^{13,38-40}$ or epidemic potential. ${ }^{39}$ Additional risk to patients could 242 stem from the fact that different strains of the same pathogen often carry different virulence genes. ${ }^{37}$ 243 Virulence factor differences in acquired strains may predispose patients to developing infections of 244 different types and severity. ${ }^{37,38}$

In addition to potentially making infections more difficult to treat, acquisition of secondary

247 strains could also increase a patient's time at risk of infection by prolonging the total period of 248 colonization. All of these potential adverse consequences of multiple strain colonization emphasize the 249 importance of protecting previously colonized patients from secondary acquisition and for healthcare providers to adhere to infection prevention protocols, even when caring for patients in cohort locations. 
medRxiv preprint doi: https://doi.org/10.1101/2020.02.07.20020669; this version posted February 7, 2020. The copyright holder for this preprint (which was not certified by peer review) is the author/funder, who has granted medRxiv a license to display the preprint in perpetuity.

It is made available under a CC-BY-NC-ND 4.0 International license .

257 time). These sampling limitations also prevent us from determining if patients remain colonized with

258 their primary strain when they become colonized with their secondary strain, or if colonization with both

259 strains persists. Thus, it is possible that cohort patients entered the facility already colonized with

260 multiple strains, and that patients did not acquire their secondary strains in the cohort. While we cannot

261 definitively rule out this possibility, the acquisition of secondary strains in the LTACH is supported by

262 the finding that 14 of the 28 patients with secondary isolates had strong genomic links $(<10$ SNVs) to

263 other LTACH patients. In total, these 14 strong genomic linkages account for $50 \%$ of the 28 index

264 patients with multiple isolates available and $11 \%$ of the 127 index patients in the full study.

265

In summary, our study provides strong evidence for cross-transmission of KPC-Kp strains within

a KPC-Kp-positive cohort, with accumulation of new antibiotic resistance genes by patients who acquire

267 secondary KPC-Kp strains. Whether acquisition of multiple KPC-Kp strains increases risk of adverse

268 patient outcomes needs to be studied further. In the meantime, we recommend robust adherence to

269 infection prevention precautions within KPC-Kp cohorts to reduce the risk of within-cohort cross-

270 transmission of KPC-Kp strains.

Acknowledgements

We thank the patients and staff of the Long-term acute-care hospital (LTACH) for their gracious 274 participation in this study; Ali Pirani for bioinformatics support and members of the Snitkin lab and the 275 Rush University/University of Michigan genomics working group for critical review of the manuscript.

276 All authors (S.E.H, M.K.H, K.L, R.D.Y, R.A.W, M.Y.L, and E.S.S) report no conflicts of interest.

278 Financial support

279 This work was supported by CDC U54 CK00016 04S2 and CDC U54 CK000481. 
medRxiv preprint doi: https://doi.org/10.1101/2020.02.07.20020669; this version posted February 7, 2020. The copyright holder for this preprint (which was not certified by peer review) is the author/funder, who has granted medRxiv a license to display the preprint in perpetuity.

It is made available under a CC-BY-NC-ND 4.0 International license .

S.E.H was supported by the University of Michigan NIH Training Program in Translational Research T32-GM1 13900 and the University of Michigan Rackham pre-doctoral fellowship.

\section{References}

1. Isolation Precautions | Guidelines Library | Infection Control | CDC. July 2019.

2. Podnos YD, Cinat ME, Wilson SE, Cooke J, Gornick W, Thrupp LD. Eradication of Multi-drug Resistant Acinetobacter from an Intensive Care Unit. Surgical Infections. 2001;2(4):297-301.

3. Laurent C, Rodriguez-Villalobos H, Rost F, et al. Intensive Care Unit Outbreak of ExtendedSpectrum $\beta$-Lactamase-Producing Klebsiella Pneumoniae Controlled by Cohorting Patients and Reinforcing Infection Control Measures. Infection Control \& Hospital Epidemiology. 2008;29(6):517-524.

4. Maragakis LL, Winkler A, Tucker MG, et al. Outbreak of Multidrug-Resistant Serratia marcescens Infection in a Neonatal Intensive Care Unit. Infection Control \& Hospital Epidemiology. 2008;29(5):418-423.

5. Snitkin ES, Zelazny AM, Thomas PJ, et al. Tracking a Hospital Outbreak of Carbapenem-Resistant Klebsiella pneumoniae with Whole-Genome Sequencing. Science Translational Medicine. 2012;4(148):148ra116-148ra116.

6. Chitnis AS, Caruthers PS, Rao AK, et al. Outbreak of Carbapenem-Resistant Enterobacteriaceae at a Long-Term Acute Care Hospital: Sustained Reductions in Transmission through Active Surveillance and Targeted Interventions. Infection Control \& Hospital Epidemiology. 2012;33(10):984-992.

7. Haverkate MR, Bootsma MCJ, Weiner S, et al. Modeling Spread of KPC-Producing Bacteria in Long-Term Acute Care Hospitals in the Chicago Region, USA. Infection Control \& Hospital Epidemiology. 2015;36(10):1148-1154.

8. CDC. The biggest antibiotic-resistant threats in the U.S. Centers for Disease Control and Prevention. November 2019.

9. Lin MY, Lyles-Banks RD, Lolans K, et al. The Importance of Long-term Acute Care Hospitals in the Regional Epidemiology of Klebsiella pneumoniae Carbapenemase-Producing Enterobacteriaceae. Clin Infect Dis. 2013;57(9):1246-1252.

10. Snitkin ES, Won S, Pirani A, et al. Integrated genomic and interfacility patient-transfer data reveal the transmission pathways of multidrug-resistant Klebsiella pneumoniae in a regional outbreak. Science Translational Medicine. 2017;9(417):eaan0093. 
medRxiv preprint doi: https://doi.org/10.1101/2020.02.07.20020669; this version posted February 7, 2020. The copyright holder for this preprint (which was not certified by peer review) is the author/funder, who has granted medRxiv a license to display the preprint in perpetuity. It is made available under a CC-BY-NC-ND 4.0 International license .

11. Hayden MK, Lin MY, Lolans K, et al. Prevention of Colonization and Infection by Klebsiella pneumoniae Carbapenemase-Producing Enterobacteriaceae in Long-term Acute-Care Hospitals. Clin Infect Dis. 2015;60(8):1153-1161.

12. Holt KE, Wertheim H, Zadoks RN, et al. Genomic analysis of diversity, population structure, virulence, and antimicrobial resistance in Klebsiella pneumoniae, an urgent threat to public health. PNAS. 2015;112(27):E3574-E3581.

13. Wyres KL, Holt KE. Klebsiella pneumoniae Population Genomics and Antimicrobial-Resistant Clones. Trends in Microbiology. 2016;24(12):944-956.

14. Paul M, Shani V, Muchtar E, Kariv G, Robenshtok E, Leibovici L. Systematic Review and MetaAnalysis of the Efficacy of Appropriate Empiric Antibiotic Therapy for Sepsis. Antimicrob Agents Chemother. 2010;54(11):4851-4863.

15. Sick AC, Tschudin-Sutter S, Turnbull AE, Weissman SJ, Tamma PD. Empiric Combination Therapy for Gram-Negative Bacteremia. Pediatrics. 2014;133(5):e1148-e1155.

16. Micek ST, Hampton N, Kollef M. Risk Factors and Outcomes for Ineffective Empiric Treatment of Sepsis Caused by Gram-Negative Pathogens: Stratification by Onset of Infection. Antimicrob Agents Chemother. 2018;62(1):e01577-17.

17. Cuzon G, Naas T, Truong H, et al. Worldwide Diversity of Klebsiella pneumoniae That Produce $\beta$ Lactamase blaKPC-2 Gene. Emerg Infect Dis. 2010;16(9):1349-1356.

18. Halaby T, Kucukkose E, Janssen AB, et al. Genomic characterization of colistin heteroresistance in Klebsiella pneumoniae during a nosocomial outbreak. Antimicrob Agents Chemother. September 2016:AAC.01344-16.

19. Raro OHF, Lima-Morales D de, Barth AL, et al. Putative horizontal transfer of carbapenem resistance between Klebsiella pneumoniae and Kluyvera ascorbata during abdominal infection: A case report. Infection Control \& Hospital Epidemiology. 2019;40(4):494-496.

20. Evans DR, Griffith MP, Mustapha MM, et al. Comprehensive analysis of horizontal gene transfer among multidrug-resistant bacterial pathogens in a single hospital. bioRxiv. November 2019:844449.

21. Babraham Bioinformatics - FastQC A Quality Control tool for High Throughput Sequence Data.

22. Bolger AM, Lohse M, Usadel B. Trimmomatic: a flexible trimmer for Illumina sequence data. Bioinformatics. 2014;30(15):2114-2120.

23. Coil D, Jospin G, Darling AE. A5-miseq: an updated pipeline to assemble microbial genomes from Illumina MiSeq data. Bioinformatics. 2015;31(4):587-589.

24. Han JH, Lapp Z, Bushman F, et al. Whole-Genome Sequencing To Identify Drivers of Carbapenem-Resistant Klebsiella pneumoniae Transmission within and between Regional LongTerm Acute-Care Hospitals. Antimicrobial Agents and Chemotherapy. 2019;63(11):e01622-19. 
medRxiv preprint doi: https://doi.org/10.1101/2020.02.07.20020669; this version posted February 7, 2020. The copyright holder for this preprint (which was not certified by peer review) is the author/funder, who has granted medRxiv a license to display the preprint in perpetuity.

It is made available under a CC-BY-NC-ND 4.0 International license .

25. Li H, Handsaker B, Wysoker A, et al. The Sequence Alignment/Map format and SAMtools. Bioinformatics. 2009;25(16):2078-2079.

26. Kanamori H, Parobek CM, Juliano JJ, et al. A prolonged outbreak of KPC-3-producing Enterobacter cloacae and Klebsiella pneumoniae driven by multiple mechanisms of resistance transmission at a large academic burn center. Antimicrob Agents Chemother. December 2016:AAC.01516-16.

27. Cerqueira GC, Earl AM, Ernst CM, et al. Multi-institute analysis of carbapenem resistance reveals remarkable diversity, unexplained mechanisms, and limited clonal outbreaks. PNAS. 2017;114(5):1135-1140.

28. Yahav D, Farbman L, Leibovici L, Paul M. Colistin: new lessons on an old antibiotic. Clinical Microbiology and Infection. 2012;18(1):18-29.

29. Aghapour Z, Gholizadeh P, Ganbarov K, et al. Molecular mechanisms related to colistin resistance in Enterobacteriaceae. Infect Drug Resist. 2019;12:965-975.

30. Bialvaei AZ, Kafil HS. Colistin, mechanisms and prevalence of resistance. Current Medical Research and Opinion. 2015;31(4):707-721.

31. Capone A, Giannella M, Fortini D, et al. High rate of colistin resistance among patients with carbapenem-resistant Klebsiella pneumoniae infection accounts for an excess of mortality. Clinical Microbiology and Infection. 2013;19(1):E23-E30.

32. McConville TH, Sullivan SB, Gomez-Simmonds A, Whittier S, Uhlemann A-C. Carbapenemresistant Enterobacteriaceae colonization (CRE) and subsequent risk of infection and 90-day mortality in critically ill patients, an observational study. PLoS One. 2017;12(10).

33. Martin RM, Cao J, Brisse S, et al. Molecular Epidemiology of Colonizing and Infecting Isolates of Klebsiella pneumoniae. mSphere. 2016;1(5):e00261-16.

34. Tischendorf J, de Avila RA, Safdar N. Risk of infection following colonization with carbapenemresistant Enterobactericeae: A systematic review. American Journal of Infection Control. 2016;44(5):539-543.

35. Gorrie CL, Mirčeta M, Wick RR, et al. Gastrointestinal Carriage Is a Major Reservoir of Klebsiella pneumoniae Infection in Intensive Care Patients. Clin Infect Dis. 2017;65(2):208-215.

36. Otter JA, Doumith M, Davies F, et al. Emergence and clonal spread of colistin resistance due to multiple mutational mechanisms in carbapenemase-producing Klebsiella pneumoniae in London. Sci Rep. 2017;7.

37. Wyres KL, Wick RR, Judd LM, et al. Distinct evolutionary dynamics of horizontal gene transfer in drug resistant and virulent clones of Klebsiella pneumoniae. PLOS Genetics. 2019;15(4):e1008114.

38. Martin RM, Bachman MA. Colonization, Infection, and the Accessory Genome of Klebsiella pneumoniae. Front Cell Infect Microbiol. 2018;8. 
medRxiv preprint doi: https://doi.org/10.1101/2020.02.07.20020669; this version posted February 7, 2020. The copyright holder for this preprint (which was not certified by peer review) is the author/funder, who has granted medRxiv a license to display the preprint in perpetuity.

It is made available under a CC-BY-NC-ND 4.0 International license .

39. Gu D, Dong N, Zheng Z, et al. A fatal outbreak of ST11 carbapenem-resistant hypervirulent Klebsiella pneumoniae in a Chinese hospital: a molecular epidemiological study. The Lancet Infectious Diseases.

40. Russo TA, Marr CM. Hypervirulent Klebsiella pneumoniae. Clinical Microbiology Reviews. 2019;32(3).

\section{Figure legends}

Figure 1. KPC-Kp isolates from convenience sample of patients who were positive at the study

start or admission to the LTACH. Patients $(\mathrm{N}=28)$ have primary and secondary isolates that are from the same MLST, different MLST or both same and different MLST. Y-axis indicates patients, X-axis indicates bi-weekly time-periods during the study, circles indicate positive culture dates and are colored by the MLST of the isolate collected. Grey bars indicate when patients were in the LTACH.

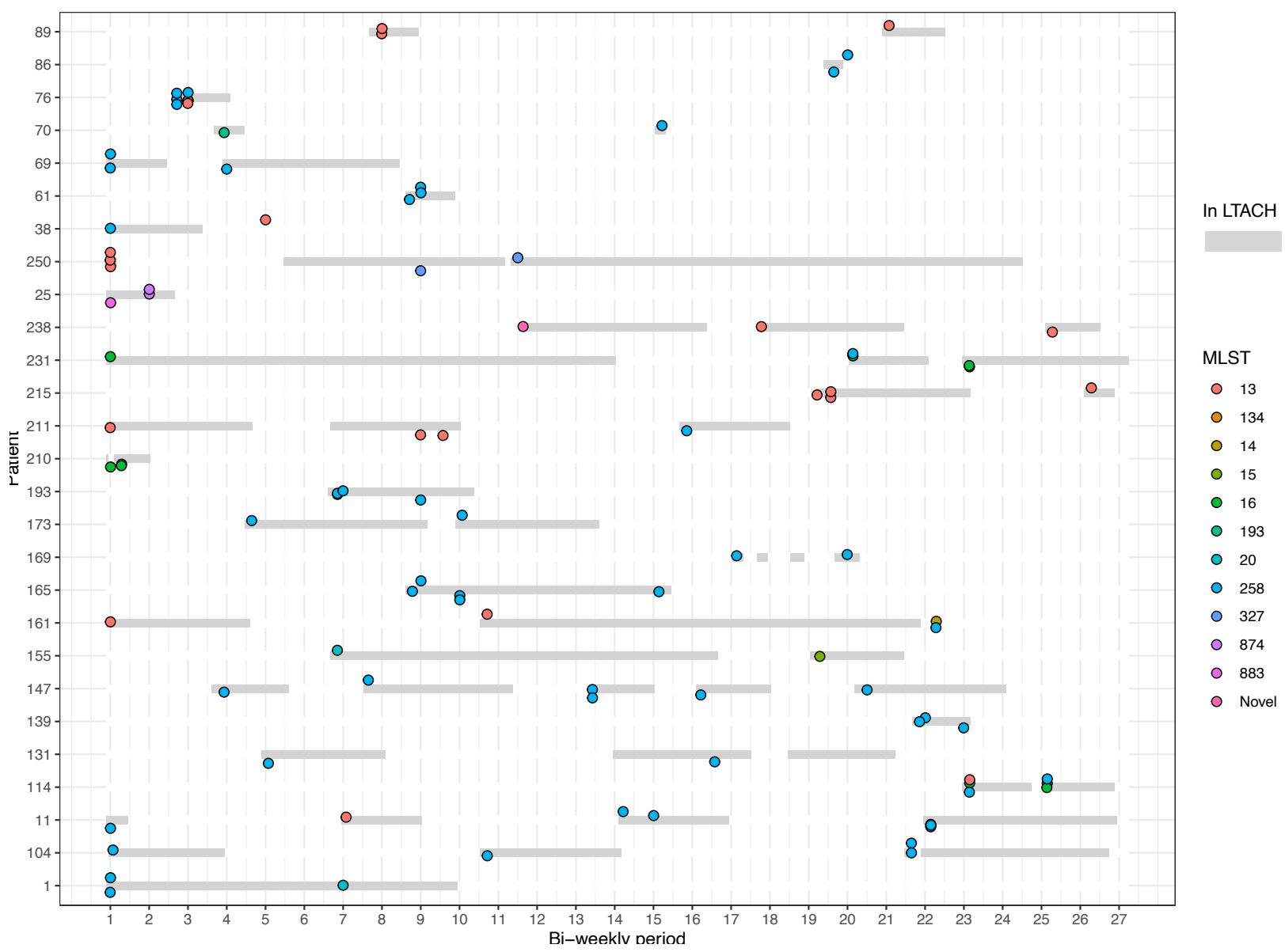


medRxiv preprint doi: https://doi.org/10.1101/2020.02.07.20020669; this version posted February 7, 2020. The copyright holder for this preprint (which was not certified by peer review) is the author/funder, who has granted medRxiv a license to display the preprint in perpetuity.

It is made available under a CC-BY-NC-ND 4.0 International license .

396 Figure 2. Genetic relationship between a patient's primary and secondary isolates compared to

397 isolates from other patients in the LTACH and room cohorts. Pairwise SNV distance between

398 secondary isolates and closest primary isolate from the same patient compared to closest related isolate

399 from A. another patient in the facility or B. a cohorted roommate. Diagonal line separates secondary

400 isolates that are more closely related to primary isolates from the same patient (above the diagonal) or to

401 another patient's isolate (below the diagonal). Colors indicate the MLST of the secondary isolate.

402 Circles indicate the closest genetic relative to the isolate by SNV distance is from the same patient (e.g.

403 the patient's own primary isolate) while triangles indicate that the closest relative was isolated from

404 another patient. Comparison of isolates from different MLSTs or $>100$ SNVs are collapsed into the

$405>100$ SNV category for plot visualization purposes.

406 
medRxiv preprint doi: https://doi.org/10.1101/2020.02.07.20020669; this version posted February 7, 2020. The copyright holder for this preprint (which was not certified by peer review) is the author/funder, who has granted medRxiv a license to display the preprint in perpetuity.

$$
\text { It is made available under a CC-BY-NC-ND } 4.0 \text { International license. }
$$

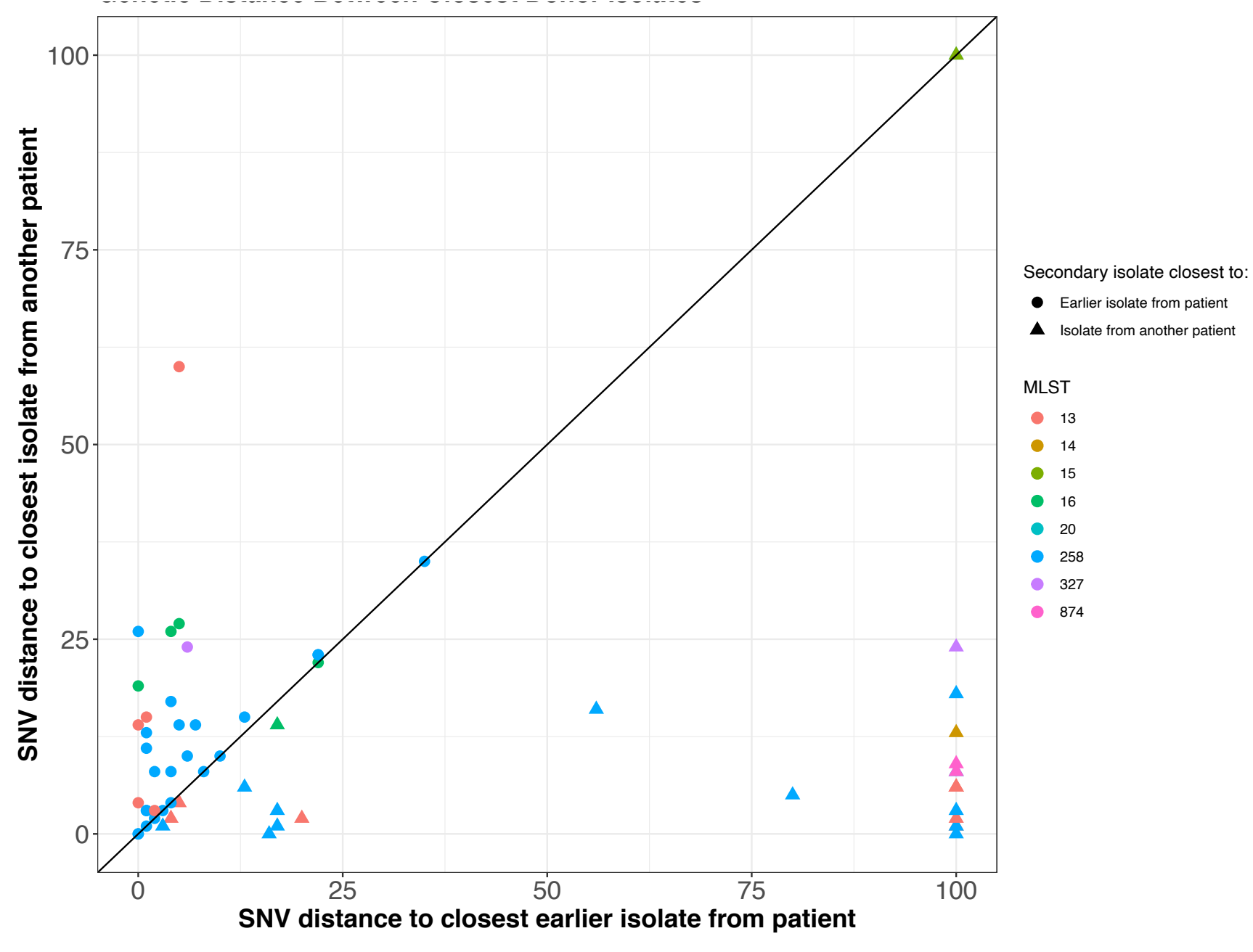




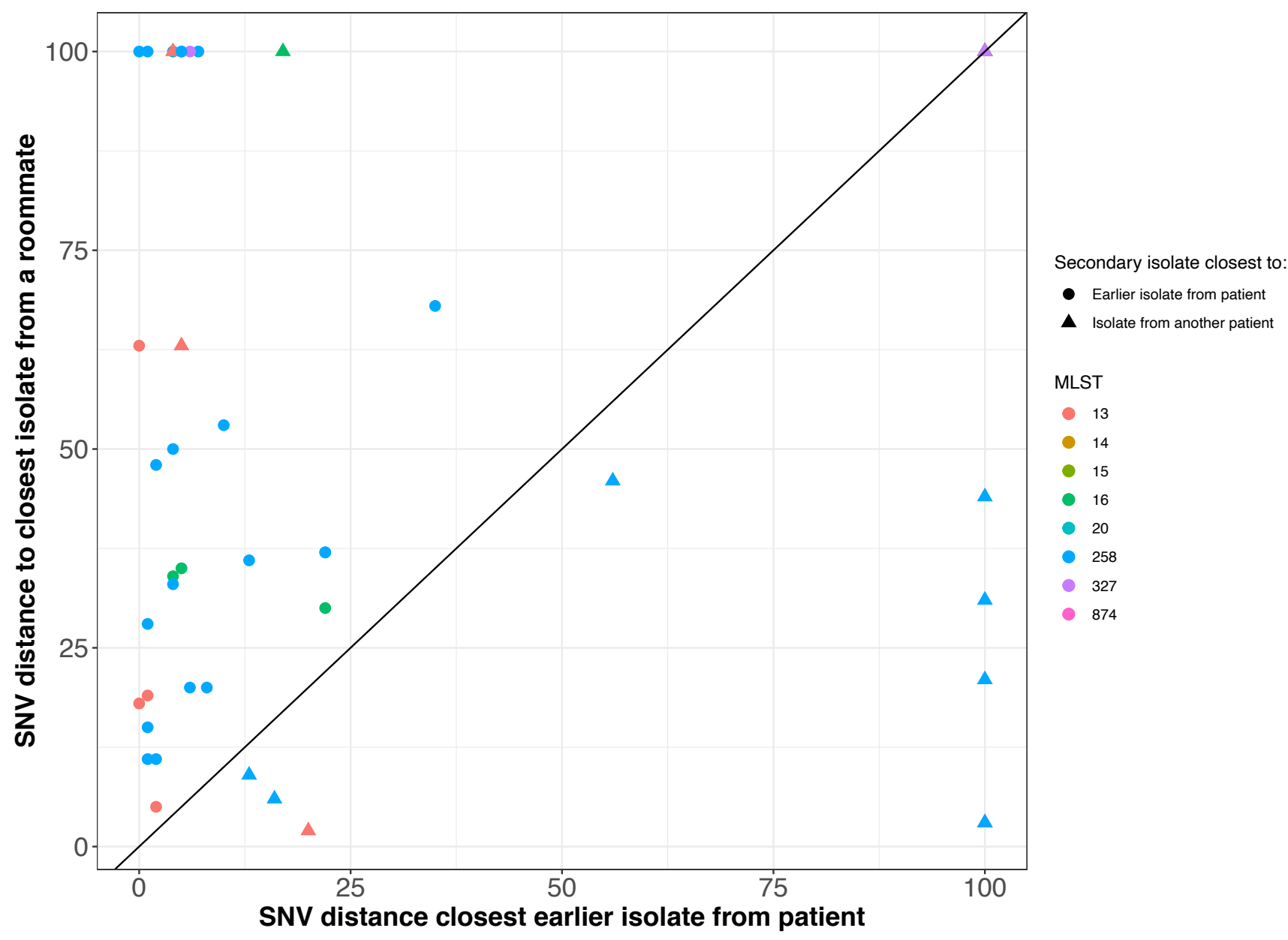

Figure 3. Number of antibiotic resistance genes detected in genomes from primary isolates

413 indicates number of unique resistance genes detected with Kleborate (See methods, Supplementary table

414 1), X-axis indicates number of unique antibiotic resistance genes detected among primary (left) and 415 primary and secondary isolates (right). Colors distinguish patients. Dashed lines indicate patients whose secondary isolate is within $10 \mathrm{SNV}$ of an isolate from a cohorted roommate. 
medRxiv preprint doi: https://doi.org/10.1101/2020.02.07.20020669; this version posted February 7, 2020. The copyright holder for this preprint (which was not certified by peer review) is the author/funder, who has granted medRxiv a license to display the preprint in perpetuity.

\section{It is made available under a CC-BY-NC-ND 4.0 International license .}

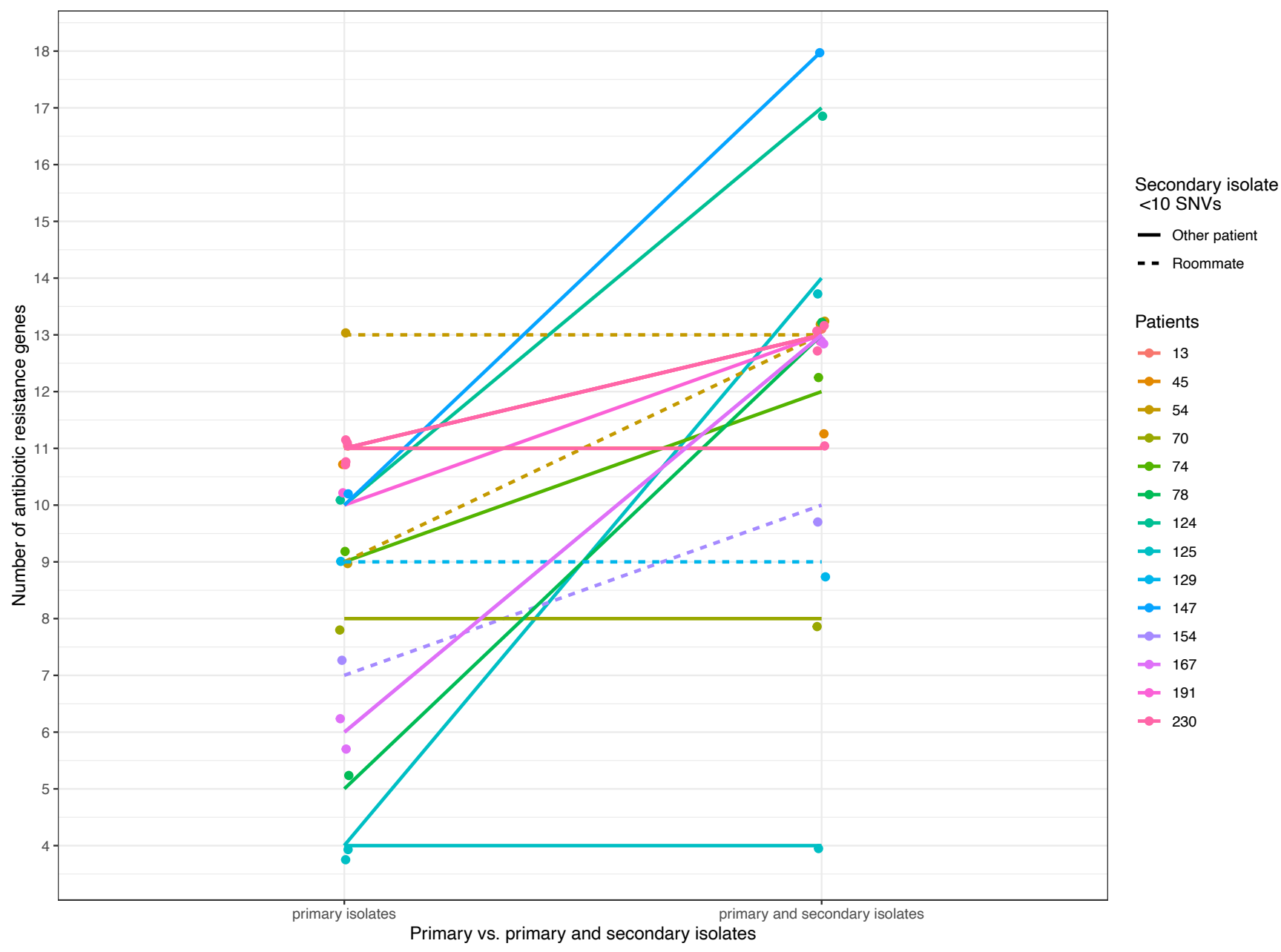


medRxiv preprint doi: https://doi.org/10.1101/2020.02.07.20020669; this version posted February 7, 2020. The copyright holder for this preprint (which was not certified by peer review) is the author/funder, who has granted medRxiv a license to display the preprint in perpetuity.

Tables

423 Table 1. Frequency of strong genetic relationships between secondary isolates and isolates from

424 other patients among patients whose primary isolate is most closely related to another patient's

425 isolate.

\# Index patients, $\mathrm{N}=28<25 \mathrm{SNV} \quad<10 \mathrm{SNV} \quad<5 \mathrm{SNV}$

(\# Secondary isolates, $\mathrm{N}=63$ )

Distance to closest isolate from $17(26) \quad 14(21)$

another LTACH patient

Distance to closest isolate from 15(19)

$12(15)$

$10(11)$

patient on cohort floor

Distance to closest isolate from $5(6) \quad 4(5)$
roommate in cohort

Table 2. Summary of antibiotic resistance genes among primary, secondary and all isolates from

427 index patients whose secondary isolate is most closely related to another patient's isolate.

\begin{tabular}{|l|l|l|l|}
\hline & Min. & Median & Max. \\
\hline Antibiotic resistance genes & 4 & 9.5 & 13 \\
\hline Antibiotic resistance genes & 0 & 2.5 & 10 \\
detected in secondary isolates & & 13 & 18 \\
\hline $\begin{array}{l}\text { Total unique antibiotic } \\
\text { resistance genes in primary }\end{array}$ & 4 & & \\
and secondary isolates & & & \\
\hline
\end{tabular}

